Discursive legitimation of a contested actor over time:

The multinational corporation as a historical case (1964-2012)

\author{
Joost Luyckx \\ KU Leuven \\ Faculty of Economics \& Business \\ Department of Work and Organisation Studies \\ Naamsestraat 69, 3000 Leuven \\ Belgium \\ E-mail: joost.luyckx@kuleuven.be \\ Phone: 32-16-326867 \\ Fax: 32-16-326732 \\ $\&$ \\ Maddy Janssens \\ KU Leuven \\ Faculty of Economics \& Business \\ Department of Work and Organisation Studies \\ Naamsestraat 69, 3000 Leuven \\ Belgium \\ E-mail: maddy.janssens@kuleuven.be \\ Phone: 32-16-326874 \\ Fax: 32-16-326732
}

Corresponding author: Joost Luyckx

This is a so-called personal version (author's manuscript as accepted for publishing after the review process but prior to final layout and copyediting) of the article. Researchers are kindly asked to use the official publication in references. See:

J. Luyckx \& M. Janssens (2016). Discursive legitimation of a contested actor over time: The multinational corporation as a historical case (1964-2012). Organization Studies, 37(11), pp. 1595-1619, doi: 10.1177/0170840616655493

http://oss.sagepub.com/content/37/11/1595 


\title{
Discursive legitimation of a contested actor over time: \\ The multinational corporation as a historical case (1964-2012)
}

\begin{abstract}
In this study, we explicitly engage with the historical dimension of discursive legitimation to understand how a sense of legitimacy is maintained for a controversial actor over a long period of time. Analyzing articles in The Economist that address opposition against MNCs during the current wave of globalization, we identify and situate the different MNC-related controversies and discursive legitimation strategies in their specific historical context. Our historical interpretation suggests three phases, each representing the discursive creation of particular actor images that either legitimize MNCs or delegitimize its opponents. From our findings, we propose that, over time, the nature of discursive legitimation changes and introduce 'discursive antagonism' and 'discursive co-optation' as two different forms of legitimation. We further reflect on our present understanding of MNCs, reinterpreting their current political role as a historical product of the legitimacy process over time.
\end{abstract}

key words: legitimacy, discursive legitimation, multinational corporations, controversies, historical organization studies, periodization, political CSR 


\section{INTRODUCTION}

This study aims to understand discursive legitimation of a controversial actor over time. A discursive approach to legitimacy or a sense of "social acceptability bestowed upon a set of activities or actors" (Washington \& Zajac, 2005, p. 284) understands that legitimacy is shaped through linguistic resources (Suddaby \& Greenwood, 2005; Van Leeuwen, 2007). Instead of considering legitimacy to be a property of an organization, the attention is on the role of discourses (Maguire \& Hardy, 2009) and textual strategies (Brown, Ainsworth \& Grant, 2012; Vaara \& Tienari, 2008) in the social construction of legitimacy. For the most part, this approach has been used in studies on controversial business activities (Joutsenvirta \& Vaara, 2009, 2015; Patriotta, Gond \& Schultz, 2011; Vaara, Tienari, \& Laurila, 2006) and institutional change (Glynn \& Lounsbury, 2005; Goodrick \& Reay, 2010; Green, Li \& Nohria, 2009; Suddaby \& Greenwood, 2005). The former have analyzed the opposing language use that characterizes the legitimacy struggle over a particular controversy; the latter have focused on how the institutionalization of new ideas, practices and role identities goes together with changes in language use.

The present paper takes a different approach, focusing on how a sense of legitimacy is maintained for a controversial actor over a long period of time. We believe this is very relevant to understand given that certain individual organizations (Shell, Nestlé, IMF, WTO) and types of organizations (multinational corporations, tobacco firms, weapon manufacturers, oil and mining companies) have been under public scrutiny for decades while the call for sustainable economic development and corporate social responsibility is increasing. The controversial actor under study is the multinational corporation (MNC). Very soon after the term MNC was introduced by Lilienthal in 1960, this type of organization has been blamed for environmental disasters, the loss of labor opportunities in developed countries, tax evasion, supporting totalitarian regimes, and hindering regulatory initiatives through lobbying 
campaigns (Fieldhouse, 1986; Hamdani \& Ruffing, 2015; Kobrin, 2005, Sagafi-nejad, 2008). To study how the MNC is discursively legitimated over time, we turned to the British weekly newsmagazine, The Economist, a long-lasting defender of MNCs given its editorial stance in favor of business, economic liberalism and free market globalization. Our historical time line covers the period between 1960 until 2012, a period seen as the current wave of globalization (Jones, 2008).

As the notion of time is central to our study, we explicitly engage with the historical dimension of discursive legitimation. Informed by the most recent discussions on how to bring in history into organization studies (Kipping \& Üsdiken, 2014; Maclean, Harvey \& Clegg, in press; Rowlinson, Hassard \& Decker, 2014), our epistemological stance is one of 'creative synthesis' where we combine the sensitivity of historians to historical context with the social scientific concern of organization scholars to develop theory. In terms of Maclean and colleagues' classification of different purposes for incorporating history into organizational research, it is our aim to use history to "conceptualize" or "generate new theoretical constructs" (in press, p. 12) regarding discursive legitimation. Studying the legitimation of MNCs over time, we found not only that the textual strategies to shape legitimacy change over time but also, and importantly, that the nature of discursive legitimation itself changes over time. In particular, by bringing in a historical perspective, our study is able to show that discursive legitimation can take the form of both 'discursive antagonism' and 'discursive co-optation'.

The remainder of this paper is structured as follows. As the MNC is the controversial actor under study, we review the literature on legitimation of MNC-related controversies. We argue that these studies are primarily concerned with showing the discursive struggle surrounding controversies, thereby highlighting the cultural-political nature of (de)legitimation but neglecting its historically bound nature. We then explicitly present our 
epistemological stance on history and time. In contrast to the studies on the discursive legitimation of institutional change, our study brings in history to "conceptualize" instead of "explicate" and puts forward a historical treatment of time, i.e. understanding events in their historical context, instead of clock time (Rowlinson et al., 2014). We then present our empirical study and develop, in the discussion, our main contribution that the nature of discursive legitimation changes over time. Further, as a historical approach reminds us that present organizational phenomena are historical products (Suddaby, Foster \& Mills, 2014), we re-interpret the current trend to understand MNCs as political actors, involved in socially responsible activities (Matten \& Crane, 2005; Scherer \& Palazzo, 2011) as a strategic legitimation practice.

\section{THEORETICAL BACKGROUND}

\section{The Cultural-Political Nature of Discursive Legitimation of MNCs' Controversies}

Reviewing the literature on controversies of MNC-driven globalization (Breeze, 2012; Joutsenvirta \& Vaara, 2009; 2015; Vaara et al., 2006; Vaara \& Tienari, 2008; Zhu \& McKenna, 2012), our main argument is that it tends to highlight the cultural-political meaning of legitimation in their empirical analysis, while neglecting its historically bound nature.

Given these studies' concern to show the struggle around a particular controversy, they emphasize the opposing discourses that actors rely on to (de)-legitimize the MNC activity. For example, discourses of neo-liberalism and free market globalization portray MNCs' activities as inevitable (Breeze, 2012; Erkama \& Vaara, 2010; Vaara \& Tienari, 2008); whereas radical humanist, Marxist, or nationalistic discourses de-legitimize them (Vaara \& Tienari, 2008; Zhu \& McKenna, 2012). Further, the presence of opposing discourses has instigated scholars to identify types of discursive struggles, emphasizing how actors purposely deploy particular discourse(s) for their own advantage. For example, 
studying a contested Finnish greenfield project in Uruguay, Joutsenvirta and Vaara (2009) highlighted three types of discursive struggle - legalistic struggles, truth struggles, and political struggles, and argued that corporate representatives tend to highlight the legalistic discourse, aiming to distance themselves from a discourse that emphasizes the political role of the company.

These studies thus provide compelling examples of the cultural-political nature of the legitimation process. Yet, they tend to neglect the historical context when analyzing the (de)legitimation of a particular controversy. For instance, they do not explicitly examine how the firm's history of controversies (or good behavior) matters, or to what extent the observed language used to (de)legitimate is specific to the cultural meaning system of the time period in which the controversy is located. The same is the case when examining the textual strategies through which actors try to control the public debate. They are described to primarily show their persuasiveness in establishing a sense of legitimacy, yet without acknowledgment of previous (un)successful attempts or their specificity to the cultural meaning system of the time period.

To understand legitimacy maintenance of MNCs over time, we build on these studies in terms of the textual strategies that are used to legitimize MNCs, yet we explicitly incorporate the historical dimension. That the historical nature of legitimation is important is suggested by Livesey's work $(2001 ; 2002)$, a scholar in business communication. While her studies are less explicitly linked to legitimation, Livesey showed the dynamic interplay of discourses or 'discursive mingling'. For instance, analyzing ExxonMobile's advertorials on climate change, she interpreted these texts as containing new hybrid discourses (ecoefficiency) and new ideologies (responsible capitalism) whose emergence is traced back to the first texts on environmentalism in the 1960s, the Brundtland Report in 1987 and the political struggle over the environment over the last 30 years (Livesey, 2002). 
Given recent discussions on the multiple ways in which history can be brought into organization studies (Kipping \& Üsdiken, 2014; Maclean et al. in press; Rowlinson et al., 2014), we clarify in the next section our stance regarding the epistemological problem of representing the past and contrast our approach with institutional studies that use a temporal perspective.

\section{Our Epistemological Stance on History and Time}

The key assumption of this study is that the analysis of legitimation over time requires a historical approach. As Maclean and colleagues (in press) indicate, organizational scholars have different purposes for incorporating history into their research. Our study is an example of the type of research that they denote as 'history as conceptualizing'. In this case, history is used to enable the exposition of theoretical ideas and constructs as they are embedded within the story told. The value to organization studies lies therefore in the inductive generation of new theoretical constructs, which may transcend the specific historical case(s) in which they were originally examined.

To our knowledge, this type of historically informed research is rare within the field of institutional theory. Most historical studies on institutional formation and change (e.g. Hargadon \& Douglas, 2001; Hoffman, 1999; Leblebici et al. 1991; Rojas, 2010) tend to use history to "explicate" or to "reveal the operation of transformative social processes" (Maclean et al., in press, p. 11). Their value is thus different, refining institutional theory through new interpretations of past-to-present regarding institutional change. The study by Maguire \& Hardy (2009) is a notable exception, proposing the concept of 'defensive institutional work' after studying outsider-driven deinstitutionalization through a historical case study of the abandonment of DDT use. 
Taking a historical approach implies an understanding of time as being historically situated in temporal and spatial contexts (Rowlinson et al., 2014). This understanding of time is different from the social scientist tradition to treat time in longitudinal studies as analytic time or clock time, a consistent and chronological measure for the sequencing of events in processual accounts. Studies on discursive legitimation of institutional change (Navis \& Glynn, 2010; Goodrick \& Reay, 2010; Green et al., 2009) tend to follow this social scientist tradition. They present a chronological order of discursive changes, yet incorporation of historical contextual elements only occurs as background information, either in the theory or method section and is not fully acknowledged when analyzing and interpreting those discursive changes. For example, examining the institutionalization of Total Quality Management, Green and colleagues (2009) showed the changes in argument structure, shifting from syllogistic or explained in full to a simple explanation and then a single proposition. Although referring in the method section to the severe competitive pressures that US companies faced from foreign competition during that time, this historical conditionality was not fully acknowledged in their theorizing (cf. Kipping \& Üsdiken, 2014). A similar type of study by Goodrick and Reay (2010) on the legitimizing of a new professional role identity for nurses between 1932 and 2009 is more sensitive to historical context. In addition to highlighting that legitimatizing a new role identity requires the incremental development of new arguments where the past is not delegitimized, they emphasize that the former is also connected to broader societal changes.

This study interprets discursive legitimation as embedded in a particular historical context through the use of periodization. This latter refers to the analytical arrangement of certain temporal processes into distinct periods or phases with their own characteristics (Rowlinson et al., 2014; Suddaby \& Greenwood, 2009). Central hereby is that we do not consider each year as equivalent to another year (this would be time as clock time) but rather 
attend to possible meaning differences (Rowlinson et al., 2014). We thus consider divisions of social time in periods or phases not as a given, but as constructed by the researcher based on The Economist articles (primary sources) with reference to historiographical debate (secondary sources), involving the embedding of the analysis into previous scholarly interpretations (Fear, 2014; Rowlinson et al., 2014). It is through such periodization that we aim to capture the contextual unicity of each phase, showing hereby the historical embeddedness of discursive legitimation and theorizing its change over time.

\section{METHOD}

\section{Our Empirical Case: MNCs in The Economist}

To understand discursive legitimation over time, we studied the legitimation of MNCs in The Economist during the current wave of globalization. We selected MNCs as this type of organization has been controversial since the term entered the public debate in 1960. Among possible defenders of MNCs (Forbes, Fortune, The Financial Times, The Wall Street Journal), we selected The Economist for the following reasons. First, this magazine is likely to provide explicit and vivid legitimation accounts of MNCs given its pro-MNC bias. Its editorial stance is in favor of political and economic liberalism, globalization, and free trade which goes hand in hand with a very positive editorial attitude towards corporations and MNCs in particular - as explicitly stated by the magazine (06-26-1976). That this stance is typical for the magazine and not only individual authors' opinions is reflected in the practice that articles are published anonymously. Second, it is likely that this magazine informs us about the main controversies that MNCs encountered during the current wave of globalization. Because of its elite reader profile - The Economist targets highly educated readers, containing influential business executives and politicians - and its geographically global spread, - circulating in over 200 countries - we can expect that the magazine reports on 
MNC-related issues which are of public interest on a supra-national and even global scale. Third, the availability of online historical archives of The Economist, which range from 1843 (first issue) until now, and the uninterrupted publication of the magazine from 1950 on allowed us to carry out this study.

\section{Sampling Articles}

We conducted the sampling in January 2013 by using the 'The Economist Historical Archive' of Gale Cengage Learning (containing all articles that were published until 2006) and the search-function on the homepage of The Economist (for the period 2006-2012). We applied the keywords 'multinationals', ‘multinational corporations', 'multinational companies', 'multinational firms', 'multi-national corporations', 'multi-national companies', 'transnational corporations', expecting to capture all articles on MNC-related controversies. This initial search resulted in more than 4000 articles (duplicates included), with the first article on MNCs being published on 17 October 1964, four years after the term MNC was introduced by Lilienthal (1960).

We then conducted a further screening on the two following criteria. First, as legitimation is likely to be vividly present when outsiders try to abandon existing activities (cf. Maguire \& Hardy, 2009), we selected those articles which reported on public controversies around MNCs. Understanding a controversy along the meaning of a legitimacy test or "disruptive occurrences... of a public and collective nature" (Patriotta et al., 2011, p. 1807-1808), we screened all articles on whether or not they mentioned opposition against MNCs by stakeholders. This resulted in 129 articles. This major reduction was due to our initial use of broad keywords, capturing also advertisements, letters to the editor, reviews of corporate histories, executives' biographies, and technical reports on themes such as stock market evolutions, the success of MNCs from particular countries, the level of FDI, effective 
strategies to manage a MNC and the level of globalization in different economic sectors.

To further ensure that we captured all information on MNCs-related controversies, we performed an additional search based on the content of the 129 articles. Considering that other articles (not mentioning the term multinational) might report on the same controversial topics, we used the keywords 'Shell', 'Greenpeace', 'sweatshop', 'NGOs', 'activists groups', 'antibusiness activists' and 'Naomi Klein', and examined the table of contents for each of the issues in which the 129 articles were published. This resulted in 16 additional articles. The total of 145 articles were the data on which we performed our periodization of the controversies around MNCs.

Second, focusing on discursive legitimation, we screened the 145 articles on the presence of textual strategies to portray MNCs in an acceptable and/or desirable way. In line with our understanding of legitimacy as constructed through discourses and textual strategies, we included articles if they contained justificatory practices "providing reasons, grounds or acceptable motivations for past or present actions criticized by others" (Van Dijk, 1998, p. 255). This screening resulted in a total of 95 articles for further in-depth analysis of the legitimation strategies.

\section{Analysis of Empirical Material}

MNCs-related controversies within their historical context. We began with a thematic analysis, which is argued to be a first dimension of a discourse-analytic approach (Wodak, 2001) and a commended way to start critically oriented media analysis (Vaara et al., 2006). This analysis led to an understanding of the specific contents of the controversies. In line with our historical approach, we then turned to secondary sources to further understand the different controversies within their particular historical context (Rowlinson et al., 2014). In particular, we relied on various types of literature: business history (Fieldhouse, 1986; Kobrin, 
2005), contemporary history (Mazower, 1998; Eckes Jr., 2011), historical accounts produced and disseminated by the UN (Hamdani \& Ruffing, 2015; Sagafi-nejad, 2008), left- and rightwing advocacy journalism (Klein, 1999; 2007; Norberg, 2003), sociology of globalization (Fiss \& Hirsch, 2005); transnational law (Murphy, 2005; Stanley, 1980), business ethics and corporate social responsibility (Kell, 2013; Levy \& Kaplan, 2008), and international relations (Van de Meerssche, 2006; Vernon, 1998). For the most recent historical developments after 2006, however, it was difficult to find relevant publications. We therefore relied on newspaper reporting on anti-capitalist protest activities from The New York Times and The Guardian.

Inductively identifying distinct periods or phases. Having interpreted the different controversies within their broader socio-political and historical context, we inductively arranged them into distinct periods or phases (Rowlinson et al., 2014). Understanding phases as "relatively distinct and coherent clusters of activity, temporally bracketed, and organized around common themes" (Suddaby \& Greenwood, 2009, p. 184), we identified three distinct phases in the discursive legitimation of MNCs. They emerged as we noted that different types of controversies situated in a particular socio-political and historical context came to the fore, along with different actors questioning the legitimation of MNCs. We further noted how in each phase the intensity of legitimation differed.

Identifying suitable start and end points of historical periods is however challenging as different researchers may judge the same events differently on their significance (Rowlinson et al., 2014; Suddaby \& Greenwood, 2009). In our study, we decided on the turning points for the following reasons. The first phase ranges from 1964 until 1988. We decided on 1964 as starting point as it was then that the first article on opposition against MNCs appeared. The phase ends in 1988, when the final article about the controversy of that time was published. We then noted that references to MNCs' controversies subsided almost completely for about 
seven years (transitional phase between 1989-1994). The second phase ranges from 1995 until 2005. As the Brent Spar case in 1995 clearly triggered this phase, we took 1995 as starting date. The year 2006 was a transition year, with no articles on controversies. From 2007 on, we noticed the start of a new phase, coinciding with the Great Recession.

Table I gives an overview of our periodization regarding MNC-related controversies over time: 'The MNC within the North-South dialogue', 'The MNC in the anti-globalist era', and 'The MNC and the Great Recession'. Categorizing our data set of 145 magazine articles along these three phases, we found 61 articles between 1964 and 1988, 45 articles between 1995 and 2005, and 34 articles between 2007 and 2012. Five articles appeared during the transitional phase (1989-1994), mentioning some form of opposition against MNCs, however, without substantial discursive legitimation.

Insert Table I about here

Discursive legitimation strategies. Having distinguished three phases of MNCs' controversies, we performed for each phase a textual analysis to study how MNCs were discursively legitimized. We initially relied on Van Leeuwen's 'grammar of legitimation' (Van Leeuwen, 2007; Van Leeuwen \& Wodak, 1999) as his model of discursive strategies was specifically developed for legitimation as well as later used by studies on discursive legitimation of MNCs and journalistic practices (Vaara et al., 2006; Vaara \& Tienari, 2008). When making sense of our material from this model, we found three legitimation strategies that The Economist extensively used: 'authorization', 'rationalization' and 'moral evaluation'. While the first two strategies well matched onto our empirical material, the latter strategy of moral evaluation required further refinement. Going back and forth between our data and other theoretical notions on discursive strategies, we distinguished two sub-types of moral 
evaluation: 'amoralization' (Crane, 2000) and 'improvement' (Sillince \& Brown, 2009).

In addition to these four strategies of legitimizing MNCs' activities, we saw that The Economist tended to rely on additional discursive strategies to de-legitimize the opponents' critiques. To interpret these strategies, we again used an abductive way of interpreting which led to the distinguishing of three additional types of legitimation strategy: 'a predicational strategy', 'a referential strategy', and 'refutation by wit'. The two first strategies are types of discursive strategies which belong to the classification by Wodak (2001, p. 73) involving "the positive self- and negative other presentation" and turned out to be very useful for interpreting how The Economist portrayed the opponents of MNCs. 'Refutation by wit', a classical rhetorical strategy, was used to further undermine the credibility of the opponents through the wittily reduction of their particular arguments to absurdity (Corbett \& Connors, 1999). Table II presents a definition and illustrations of the seven discursive legitimation strategies.

Insert Table II about here

Whereas discursive studies often rely on frequencies to indicate the importance of particular strategies (Joutsenvirta, 2013; Joutsenvirta \& Vaara, 2009; 2015), we decided not to do so as, in our case, the importance of a discursive strategy is also influenced by its visibility. The visibility of the articles varied enormously, ranging from cover pages, first articles of an issue, multiple page articles with cartoons to small articles in the middle or end of an issue. Also, articles appearing right after specific incidents which triggered new or fed existing controversies deserve special attention, as they were written at a time when the need for legitimation was particularly high. So, the importance of discursive strategies is hard to capture by frequencies. Rather, the strategies we present here are the ones that emerged from our interpretive analysis as the most visible throughout the magazine in the last fifty years. 


\section{PHASES OF MNCs’ DISCURSIVE LEGITIMATION}

\section{Phase 1 (1964-1988): The MNC within the North-South dialogue}

Controversy on codes of conduct. In the first phase, between 1964 and 1988, the legitimation of MNCs was mainly questioned by governments of developing countries, critical academics, and Western labor unions who raised concerns about MNCs' uncontrolled power and initiated discussion on the need for universal codes of conduct for MNCs. During this period, The Economist articles often mentioned this internationally shared concern that MNCs could act against the interests of nation-states by abusing their size and international structure. Other authors (Fieldhouse, 1986; Kobrin, 2005; Vernon, 1998) also mention this controversy, indicating it increased during the 1970s. The following excerpt from The Economist satirically summarized the various issues surrounding MNCs in those years:

It fiddles its accounts. It avoids or evades its taxes. It rigs its intra-company transfer prices. It is run by foreigners, from decision centres thousands of miles away. It imports foreign labour practices. It doesn't import foreign labour practices. It overpays. It underpays. It competes unfairly with local firms. It is in cahoots with local firms. It exports jobs from rich countries. It is an instrument of rich countries' imperialism. The technologies it brings to the third world are old-fashioned. No, they are too modern. It meddles. It bribes. Nobody can control it. It wrecks balances of payments. It overturns economic policies. It plays off governments against each other to get the biggest investment incentives.

(Controlling the multinationals, The Economist, January $24^{\text {th }}, 1976$ )

This detailed characterization of MNC criticism contained already an explicit reference to the 'race to the bottom' theory as well as to the relation between the developing and developed world. This relation is an important aspect of the historical context in which this controversy is embedded. At that time, the economic dominance of the industrialized world was questioned by a loose coalition of 77 developing countries within the UN General Assembly (the Group of 77), who argued for a 'New International Economic Order' with a more fair distribution of welfare across the globe (Eckes Jr, 2011; Sagafi-nejad, 2008; Stanley, 1980; 
Van de Meerssche, 2006). In this so-called North-South dialogue, much attention went to MNCs as many developing countries felt threatened to be exploited by powerful and predominantly American and Western European MNCs, which were often considered as the main instruments of neocolonialism (Eckes Jr, 2011; Van de Meerssche, 2006).

Within this political-historical context, various supranational entities (e.g. ILO, UN, OECD, EC) showed the intention to compose codes of conduct for MNCs (Murphy, 2005; Sagafi-nejad, 2008). During the 1970s and the 1980s, there was much argument over the content of these guidelines, with some actors (Western labor unions, third world countries' political leaders) arguing them to be mandatory whereas others (mostly certain governments of developed countries) favored a voluntary approach. The underlying tenet of this debate referred to the question of the most suitable global economic model. For actors advocating global free market capitalism, MNCs were the major force in driving up the global economy, whereas for actors supporting a regulated economic model, universal codes of conduct were necessary to avoid abuse.

Also The Economist reported on the first voluntary code of conduct for MNCs (06-261976), which was published in 1976 by the OECD. While the magazine was in favor of business, its attitude regarding a universal code of conduct for MNCs was rather ambiguous. It occasionally supported the idea - the OECD guidelines were considered to be too weak but also expressed skepticism. At the end of the 1980s, a time characterized by increasing hostility of the US administration towards a UN code of conduct for MNCs (Sagafi-nejad, 2008), the magazine published a polemic article refuting the idea of a UN code (November 1988). With this point of view, The Economist joined the side of other influentially business media like the Wall Street Journal, who had claimed that the UN was too hostile to the business world in its attempts to draft a code of conduct for MNCs (Sagafi-nejad, 2008). 
this phase, we note that explicit debate and refutation of criticism - which we call 'discursive antagonism' - were dominant. In particular, to counter the opposition, The Economist constructed a positive actor image of MNCs that was opposite to the race to the bottom arguments, as well as a negative actor image of the critics that undermined their credibility.

Actor image of MNCs: A source of welfare. Explicit refutation of criticism was found in the way The Economist relied on a combination of 'rationalization' and 'authorization' (Van Leeuwen \& Wodak, 1999) to construct MNCs as sources of welfare, income and jobs, to the benefit and self-interest of individuals all over the world. Especially factual information and figures acquired from reports of established institutions with a high reputation, such as ILO, UN and academic research, were repeatedly employed to emphasize the utility of MNCs as a powerful force for good in global society. The following passage from the polemic article rejecting the possible introduction of a UN code of conduct for MNCs illustrates:

Multinationals increase employment in their host countries. The UN's conservative estimate of direct employment by multinationals is $65 \mathrm{~m}$, or $3 \%$ of the world's labour force. Add indirect employment, such as jobs created by suppliers and by the general lift to an economy that multinationals can provide - and such companies may generate $6 \%$ of world employment. American multinationals employed almost $61 / 2 \mathrm{~m}$ people abroad in 1984, 32\% of these in developing countries, $42 \%$ in Europe, 5\% in Japan and $14 \%$ in Canada.

(Come back multinationals, The Economist, November $26^{\text {th }} 1988$ )

Through combining 'neutral' economic arguments coming from reputable institutions, MNCs were legitimized in terms of the idea which was later described by Norberg (2003) as the 'race to the top theory'. They were depicted as the major force in driving up welfare, wages, investments and working conditions in the global economy because of their superior efficiency and productivity.

Actor image of opponents: Unreliable critics. Explicit refutation of criticism was further notable in the way The Economist constructed a negative actor image of the most prominent critics, portraying the latter as 'unreliable'. At that time, anti-corporate critiques were primarily disseminated by governments of developing countries (especially Latin-American 
countries with leftist governments such as Chile), critical academics like Richard Barnet, Ronald Müller, Stephen Hymer, Kari Levitt and Constantine Vaitsos, and western labor unions (Fieldhouse, 1986; Hamdani \& Ruffing, 2015; Kobrin, 2005; Levy \& Kaplan, 2008; Sagafi-nejad, 2008; Vernon, 1998). Of those, developing countries' governments were the ones mainly discussed in The Economist. To de-legitimize their criticism, the magazine relied mainly on two discursive strategies.

The Economist repeatedly employed a 'predicational strategy', relying on evaluative attributions of negative traits (Wodak, 2001) to portray them as unreliable. For example, the developing countries' governments were characterized as simply wanting to treat MNCs as they wish (e.g. bullying and unexpectedly nationalizing subsidiaries of MNCs) as well as acting against their own interests (e.g. MNCs' investments were presented as a more effective recipe for economic growth than bank loans or development aid programs). A negative portrayal was further constructed through the rhetorical strategy of 'refutation by wit' (Corbett \&Connors, 1999). Relying on particular forms of sophisticated humor such as irony and metaphors, opponents' arguments and ideas were mocked and reduced to absurdity, thereby creating a sense of incredibility (Corbett \&Connors, 1999). For example, anticorporate critics were invariably portrayed as thinking simplistically about MNCs as "bad guys" (11-22-1975) and "bogeyman" (01-24-1976 and 11-26-1988). With such parodying of anti-corporate criticism, The Economist undermined the standing of MNCs' opponents and hereby also the logic of the race to the bottom argument. Even more, it helped to frame the race to the top argument as a much more plausible and inviting explanation, hereby legitimating MNCs.

Transitional Phase: The Ideological Monopoly of Free Market Capitalism (1989-1994) While already during the 1980s the number of articles on MNCs' controversial role started to 
decrease, they were almost absent in The Economist between 1989 until 1994. Considering the secondary sources on the historical context, we note a coincidence with some major historical developments in international relations. We present them here as they inform our interpretation of the discursive legitimation strategies in the next phase.

First, the hostility of the developing world towards MNCs was seen as beginning to decrease. A number of leftist governments in Latin America - "the hotbed of anti-MNC sentiments" (Sagafi-nejad, 2008, p. 33) - were overthrown by military coups, which had severe consequences for these countries' policies towards FDI (Klein, 2007). In addition, many developing countries were confronted with substantial deficits in their balance of payments, huge national debts due to the energy crisis of 1979-1980 and the dramatic rise of interest rates in the US from 1981 until the mid-eighties (the so-called Volcker Shock). Being desperate for fresh capital and new technology, they started to exhibit a more welcoming attitude towards MNCs (Klein, 2007; Sagafi-nejad, 2008). Meanwhile, the emergence of a growing number of 'third world MNCs' also positively influenced the attitude of some of the industrializing developing countries towards MNCs (Sagafi-nejad, 2008).

Second, the 1980s were characterized by an ideological renaissance of the belief in the virtues of free market capitalism, spearheaded by the policies of US president Ronald Reagan and the British prime minister Margaret Thatcher (Klein, 2007; Sagafi-nejad, 2008). The fall of the Berlin Wall in 1989 and the collapse of the Soviet-Union in 1991 even marked the start of an ideological monopoly period for beliefs in free market capitalism and the inevitability of economic globalization, with no other political ideas powerful enough to challenge them (Klein, 2007; Mazower, 1998). This ideological era in which controversies surrounding MNCs and corporate globalization were pushed to the background is seen as lasting until the mid-1990s (Fiss \& Hirsch, 2005; Klein, 1999) as then anti-globalization protests arose. 


\section{Phase 2 (1995-2005): The MNC in the Anti-Globalist Era}

Controversy of morally irresponsible scandals. A second phase in which MNCs' sense of legitimacy was questioned ranged from 1995 until 2005. During this time, western NGOs and anti-globalist street protesters managed to bring the moral responsibility of MNCs into the public debate by revealing corporate involvement in a series of highly mediatized scandals. The Economist started to discuss this new-anti-corporate activism in 1995, when the Royal Dutch Shell Group became the subject of a large-scale media controversy resulting from its plan to dispose the oil storage 'Brent Spar' in the Atlantic Ocean and its failure to take a clear public stance against the Nigerian military junta after executing nine environmental and antiShell activists from the local Ogoni minority. The significance of these incidents can hardly be overestimated. From 1995 onwards, corporate misbehavior became the subject of largescale and highly visible anti-globalization protests in the Western world - at least 40000 antiglobalization protesters took the streets in Seattle, during the Ministerial Conference of the World Trade Organization in 1999 (Kobrin, 2005; Fiss \& Hirsch, 2005).

Different from the previous phase is that The Economist published highly visible articles on MNCs. Whereas the controversy over MNCs in terms of codes of conduct had not reached a large audience in Western industrial world, Western NGOs and anti-globalization activists probably because they have a stronger discursive power position (Banerjee, 2010) than the governments of developing countries - managed to make moral responsibility of MNCs the subject of an intense public debate. This was reflected in The Economist articles - lengthy, cartoons and pictures, some on the cover page, explicitly aiming to support the MNC against its most 'merciless' critics who accused MNCs of despoiling the environment, human rights abuses, sweatshop and child labor, unfair competition, and offshoring production.

Legitimation through discursive antagonism. In this heated anti-globalist era, we note the continuation of discursive antagonism as the dominant form of legitimation. Yet, 
compared to the previous phase, the explicit refutation strategies became extensive and polemic. This was exemplified in the construction of multiple, rather than only one, positive actor images of MNCs and the almost aggressive undermining of opponents' credibility.

Actor image of MNCs: a source of welfare. The Economist continued to construct an actor image of MNCs as a source of welfare, yet did so in very outspoken way. The following excerpt, selected from an article that was published a few weeks after the large-scale street protests during WTO Conference in Seattle, illustrates:

Beware: multinational companies are on the rampage, destroying jobs, stamping on wages and generally wrecking local economies. Or so critics of globalization make out. But a cool look at the numbers tells a different story, as is clear from a new crosscountry study by the OECD ...

Fact one: foreign firms pay their workers more than the national average - and the gap is widening. ... Fact two: in most countries, foreign firms are creating jobs faster than are their domestic counterparts. ... Fact three: foreign firms spend heavily on research and development in the countries where they invest. Fact four: foreign firms tend to export more than domestic ones. ... These benefits of foreign investment are even bigger in the OECD's poorer economies.

If facts have any power to persuade, globalisation's harshest critics ought to be changing their minds, or at least beginning to have some doubts.

(Foreign Friends, The Economist, January $8^{\text {th }} 2000$ )

Like in the previous phase, rationalization and authorization were used to portray MNCs as sources of welfare. Yet, the factual information from reputable authorities was now presented in a very polemic way, thereby aiming to give the argument a sense of irrefutability.

However, given the intensity of the debate on morally irresponsible scandals, this actor image seemed not sufficient to maintain a sense of legitimacy as The Economist articles also constructed two additional actor images that precisely address the moral nature of MNCs.

Actor image of MNCs: a morally neutral actor. In some instances, contested behavior of MNCs was represented as an understandable and reasonable business decision given the complexity of the situation and the huge investments at risk. The Economist hereby turned to the discursive strategy of 'amoralization' (Crane, 2000) aiming to construct an actor image of 
MNCs as a morally neutral actor. Relying on certain, commonly accepted knowledge claims, the articles attempted to move the debate surrounding MNCs' controversial activities out of the realm of morality (Crane, 2000). In particular, the neoliberal argument that the economies of developing countries must have incentives to grow through export in a competitive global market (without ineffective foreign aid) was repeatedly used for this purpose, as illustrated by the following excerpt:

To expect firms to behave well is easy; defining good behavior is much harder. The allegation that multinationals are exploiting the third world is often misguided. Usually, the "exploitation" consists of letting developing countries make use of what economists would call sources of comparative advantage - cheap labour, say, or greater tolerance of pollution. That is how poor countries grow less poor. Often, too, people in the rich world who rail against the exploitation of the poor are mere protectionists in disguise, afraid that competition might steal their own jobs.

(Companies and their consciences, The Economist, July 20 ${ }^{\text {th }} 1996$ )

Through arguing how poor countries should grow, this excerpt aims to produce a plausible and comprehensible explanation for controversial activities like exploitation, sweatshop labor and pollution in the third world. Establishing such a sense of moral neutrality is particularly relevant for legitimation when the controversy precisely addresses moral responsibility.

Actor image of MNCs: a morally responsible actor. Many articles additionally emphasized that certain individual MNCs were already displaying remarkable ethical behavior, thereby constructing an actor image of MNCs as morally responsible. Relying on the discursive strategy of 'improvement' (Sillince \& Brown, 2009), it was highlighted that MNCs recently made various efforts and great progress in handling all kinds of ethical issues. In the following excerpt from an article on sweatshop labor in Asia, the actions taken by toy producers Disney and Mattel were explicitly praised:

Yet the best-known multinationals, which have brands that are particularly vulnerable to criticism, have improved of late. Disney and Mattel have done more than most other firms to improve working conditions in their Asian plants (most of them contractors or licensees), that make products under their name. Both have codes of conduct ... the independent panel Mattel has set up to monitor its factories is considered a model in the 
industry, even by activists.

(Sweatshop wars, The Economist, February 27 $7^{\text {th }} 1999$ )

Presenting these MNCs as better than others and approved by activists, this strategy aims to refer to the persuasive value of the MNC's character. The MNC is portrayed as benevolent and with high moral character, countering the criticism that MNCs lack moral responsibility.

Actor image of opponents: Unreliable, self-interested and naive critics. To further maintain a sense of legitimacy, The Economist, just as in the first phase, constructed a negative actor image of its opponents through employing the predicational strategy (Wodak, 2001) and refutation by wit (Corbett \& Connors,1999). Yet, similar to the actor image of MNCs as a source of welfare, this de-legitimation occurred in a polemic, sometimes even aggressive way.

One of the key opponents were NGOs as they most visibly exposed the controversial activities of MNCs. For example, Shell was heavily criticized by Greenpeace in a world-wide high-profile media campaign. To counter their critics, The Economist articles constructed NGOs as naïve and unreasonable by making over-simplified assaults. Compared to the previous phase, the humor they hereby used lost its rather light touch. Irony took the tone of sarcasm and became aggressive and bitter in tone. During the Brent Spar case, for example, the campaigning of Greenpeace in favor of disposal of the oil storage on shore elicited the following bitterly sarcastic reaction:

It will be no surprise if workmen die dismantling them, or if some of whatever noxious muck they contain contaminates the terrestrial environment - much to the relief, no doubt, of clean-living worms in the Atlantic's abyssal ooze.

(Hollow Shell, The Economist, June 24h 1995)

This particular sarcastic swipe helps to portray Greenpeace as unreasonably foolish, hereby undermining also the logic and the credibility of their arguments.

NGOs were further labeled as organizations driven by self-interest. Throughout the 
articles, NGOs were systematically portrayed as professionally managed organizations that pretend to defend the public interest but are in reality primarily driven by organizational selfinterest, i.e., finding as many generous donors as possible. The following quote from an article discussing the conflict with NGOs illustrates this predicational strategy:

Although the utterances of NGOs are often reported in the media as if they were Holy Writ, as they have become more sophisticated - even business-like - some NGOs have selected their campaigns less for the significance of the cause than for their ability to attract publicity and to raise donations from consumers in the market for things to feel angry about.

(Living with the enemy, The Economist, August $9^{\text {th }}$ 2003)

Also anti-globalist activists were actors strongly influencing the public debate about the moral responsibility of MNCs through highly visible street protests and some influential books that were disseminated in North America and Western Europa, discussing the dark sides of corporate globalization. For instance, immediately after the 'battle of Seattle', the Canadian anti-corporate campaigner and journalist Naomi Klein released the international bestseller No Logo: Taking Aim at the Brand Bullies (1999), which dealt extensively with various kinds of questionable business practices of many famous MNCs like Gap, Mattel, McDonald's, Microsoft, Nike, Shell, and Wal-Mart. These anti-globalization activists received considerable attention in The Economist. Their credibility was systematically under attack through the predicational strategy (Wodak, 2001) of labeling them - often combined with witty metaphors - as completely naïve and unreasonable. For instance, No Logo was discussed in three extremely critical book reviews (01-29-2000, 09-08-2001, and 11-09-2002) whereby Naomi Klein is urged 'to grow up' through stinging mockery:

She gives capitalism no credit for the extraordinary progress seen in recent decades in reducing poverty and other measures of deprivation (notably child morality) in the world's poor countries. She measures the growing-pains of capitalist development not against real-world alternatives but against a Disneyesque utopia in which no poor person ever loses his job or chooses to work in a multinational factory at low wages (by rich-world standards).

(Why Naomi Klein needs to grow up, The Economist, November $9^{\text {th }}$ 2002) 
Similar to the actor image of NGOs, Naomi Klein was portrayed as naïve - living in Disney World, hereby undermining the plausibility and credibility of her (and other anti-globalists) critiques. As such, it reinforces the neo-liberal arguments legitimizing MNCs.

Legitimation through discursive co-optation. While discursive antagonism was the dominant form of legitimation in this phase, we noticed that a supplementary form of legitimation - which we call 'discursive co-optation' - appeared. In particular, additional legitimatizing occurred through staging previous opponents as 'becoming partners' of MNCs.

Actor image of opponents as becoming proponents. Remarkable, The Economist started to construct an actor image of opponents as 'becoming proponents of MNCs'. In particular, through the referential strategy of constructing in-groups and out-groups (Wodak, 2001), governments of developing countries - a major MNC opponent in the previous phase - were categorized as an actor being now very favorably towards MNCs. While they once belonged to the out-group of opponents, they now belonged to the in-group of defenders. The following quote illustrates: "the developing world, having once feared them, now competes to attract their factories" (The Economist, 07-20-1996). Given the controversy of morally irresponsible behavior it aims to counter, this actor image of the developing countries as partners of MNCs can be seen as a way to alter moral judgments of The Economist readers towards a more positive evaluation of the MNC and its activities. We further understand the possibility of this new actor image in light of the neoliberal developing policies of the industrialized countries during the 1980s (see transitional phase), which made developing countries much more dependent on foreign direct investment from MNCs (Klein, 2007; Sagafi-nejad, 2008). As a result of this completely new nomination, the third world evolved from a major critic to one of the co-producers of MNCs' sense of legitimacy. 
Controversy of tax evasion. A third and last phase, between 2007 and 2012, mainly centered around the controversy of large-scale tax evasion by MNCs. We understand this controversy as situated within the recent 'Great Recession', when a new wave of large-scale anti-capitalist criticism such as the 'Indignants' movement in Spain and the 'Occupy Wall Street' protests in New York emerged. Compared to the anti-globalization era, however, this mass protest is less focused on economic globalization and MNCs but more on a broad number of shared concerns regarding wealth inequality, large-scale unemployment, the deterioration of democracy, political corruption, and all kinds of austerity measures taken by governments. Meanwhile, bankers, financial institutions, credit rating agencies and international entities like the IMF seem to have joined the MNCs as the 'evil faces' of corporate capitalism. Nevertheless, The Economist regularly mentioned societal opposition against MNCs related to the negative environmental impact of palm oil production, executive payment, genetic modification, mining, sustainable supply chain management, resource nationalism in Africa, MNC-restructuring, oil production in Africa and Latin America, and corporate tax evasion. This latter was the most recurring MNC-related controversy during the third phase.

That the 'old' issue of tax evasion by MNCs, already discussed by The Economist in 1964, came to the foreground is understandable given the civil and political resistance against the austerity measures taken by the governments of various European countries facing growing public debt. The wide-spread tax optimization strategies of MNCs are increasingly considered to contribute to the budget deficits of the European governments. This controversy raises - as in the previous phase - questions about corporate moral responsibility with media reports on Apple, Amazon, Google and Starbucks (The Economist, 12-15-2012). Next to street protests, these celebrity firms were also formally interrogated by the British Parliament and the American Congress (The Guardian, 11-13-2012; The New York Times, 05-20-2013). 
Meanwhile, the OECD declared to reflect on new international rules for corporate taxation to close the loopholes in the tax system which MNCs are abusing today (The Guardian, 02-122013 and 07-19-2013).

Legitimation as an interplay between discursive antagonism and discursive co-optation. As controversies over MNCs became less prominent, so did flagrant legitimation attempts in The Economist. Discursive antagonism - although still present in the form of the actor image of MNCs as a morally neutral actor - lost its initial prominence and gradually, discursive cooptation, as evidenced in the last decade, became more important.

Actor image of MNCs as morally neutral actor. The only form of discursive antagonism to counter the controversy of corporate tax evasion found in the articles was the construction of an actor image of MNCs as 'morally-neutral'. Similar to presenting MNCs' contested behavior in the previous phase as an understandable, reasonable business decision, so was tax evasion legitimized by the discursive strategy of amoralization (Crane, 2000), portraying it as a natural (and thus morally neutral) way of corporate behavior. The following excerpt from a special report on offshore finance illustrates:

Because of fierce global competition, being as tax efficient as possible is just as important as keeping down labour costs and overheads, which often entails a different kind of offshoring.

The real problem is that globalisation has rendered the current system of taxing multinationals archaic. Taxation is based on national boundaries, but companies operate across continents and can easily shift money and physical assets around. Until tax systems reflect that reality, the difficulties will persist.

(Global companies have plenty of latitude to minimise their tax bills, The Economist, February 22 ${ }^{\text {nd }}$ 2007)

This passage depicts the issue of corporate tax evasion as being a direct consequence of the current archaic national tax systems and the intense global free market competition. It implicitly proposes a particular 'division of moral labor' (Mäkinen \& Kourula, 2012) where governments of nation-states, who have failed to collaborate on this matter, are accountable 
for a fair and efficient corporate taxation. It also states that MNCs have no space at all to implement any ethical considerations in their tax optimization policies, by reference to the highly competitive global environment and the widely accepted importance of cost saving for organizational survival. By disseminating this idea that tax optimization is a natural way of corporate behavior, MNCs are portrayed as a morally neutral actor, which maintains a sense of legitimacy for them within the public debate over fair taxation systems.

Actor image of opponents as becoming partners. Regarding the discursive construction of opponents, no negative actor images were present anymore. Rather, only discursive cooptation of NGOs - in the previous phase the most critical opponent - appeared. NGOs were the only societal actor repeatedly mentioned in the articles referring to MNCs and CSRissues. In contrast to the heavy criticism of the NGO-movement during the anti-globalist era, NGOs were now predominantly constructed as 'in-agreement' with the business world, hereby creating an actor image of NGOs as 'becoming a partner'. The following excerpt illustrates this referential strategy where NGOs (together with governments) are constructed as belonging to the same in-group as big firms:

Yet the battle over the Olympics paints a false picture of the current relationship between business and human-rights activists. What is striking today is how often activists, big firms and governments are in agreement about the importance of human rights, and are working together to advance them.

(Beyond the "genocide Olympics", The Economist, April 24 $4^{\text {th }} 2008$ )

Constructing NGOs as partners of MNCs in ethical issues, the magazine aims to legitimate the business community, as the widely shared and positive normative evaluation of NGOs as advocates of the public interest - and therefore being of high moral character - might be reflected to a certain extent on MNCs. This referential strategy thus constructs not only a shifting actor image of NGOs, but also one of MNCs, i.e. that of a morally responsible actor. This shift in constructing NGOs is no coincidence. While anti-corporate activism continues to be part of many NGOs' core activities, MNCs and civil society organizations seem to have 
found a new understanding through a vast increase of CSR-related initiatives in which both parties collaborate (Baur \& Schmitz, 2012; Burchell \& Cook, 2013).

\section{DISCUSSION}

In this study, we contribute to the literature on discursive legitimation by focusing on the historically bound nature of legitimation. Using 'history to conceptualize' (Maclean et al., in press) and interpreting time as historically situated (Rowlinson et al., 2014), we highlight that not only discursive legitimation strategies change over time but also, and importantly, that the nature of discursive legitimation itself changes. In particular, our findings suggest two forms of discursive legitimation: 'discursive antagonism' and 'discursive co-optation'. In this discussion, we further develop both concepts and discuss the dynamic interplay between them. In addition, as a historical approach reminds us that present organizational phenomena are historical products (Suddaby et al., 2014), we re-interpret the current trend to understand MNCs as political actors, involved in socially responsible activities (Matten \& Crane, 2005; Scherer \& Palazzo, 2007; 2011).

\section{The Nature of Discursive Legitimation: Discursive Antagonism and Discursive Co- Optation}

Building on our historically informed study, we suggest that legitimation can take two different forms: discursive antagonism and discursive co-optation. Legitimation of the MNC as a controversial actor starts with discursive antagonism and evolves, as the controversy becomes more intense, to a combination of discursive antagonism and discursive co-optation where, in the final phase, the latter is also changing the content of the former to become complementary. Figure 1 presents the changing nature of discursive legitimation over time: 
Insert Figure I about here

Discursive antagonism. Our study suggests that in the beginning, a sense of legitimacy is maintained through explicit dispute, confrontation, and refutation of criticism, which we label 'discursive antagonism'. To counter the first controversy, the legitimation process primarily denies the critique and discredits the criticism and its advocates, hereby reproducing, even reinforcing existing hostilities with opponents. In particular, considering the actor images in our study, we suggest that discursive antagonism consists of counternarratives that aim to produce a positive image of the actor under scrutiny which is opposite to the criticism as well as a negative image of the opponents to undermine their credibility. Inspired by sociological work on civil discourse (Jacobs, 1996; Alexander \& Smith, 1993), we understand these two counter-narratives of discursive antagonism as the construction of a binary structure to 'purify' the actor under scrutiny and to 'pollute' the most prominent critics.

Purifying one's own image, the first aspect of discursive antagonism, is done by constructing an actor image that portrays the self as "heroic... rational and controlled in their motivations, open and trusting in their relationships, and regulated by impersonal rules in their organizational activities" (Jacobs, 1996, p. 1244-1245). In our study, such purification of the self is illustrated by the actor image of 'MNCs a source of welfare', casted to counter the criticism of that time that portray MNCs as responsible for 'the race to the bottom'.

To construct such antipodal actor image, the traditional discursive strategies such as authorization, rationalization and moral evaluation were found to be all suitable. This is unlike previous discursive legitimation studies (Joutsenvirta, 2013; Vaara \& Tienari, 2008), which tend to treat the various discursive strategies of Van Leeuwen and colleagues as fundamentally different ways to shape legitimacy. Yet, our study indicates otherwise. Considering the use of discursive strategies over time, we suggest that they, irrespectively of 
their different foci, can serve the same aim, i.e. producing a particular actor image within a cultural meaning system.

Next to purifying one's own image, we propose that discursive antagonism is characterized by polluting one's opponents, a kind of legitimation process that previous research on legitimation within management and organization studies have not yet attended to. The pollution or discrediting of actors' opposition is done by constructing an actor image that portrays those opponents as "irrational and uncontrolled in their motivations, secretive and deceitful in their relationships, and arbitrary and factionalized in their organizational activities" (Jacobs, 1996, p. 1245). In our study, the construction of a polluting actor image occurred through the discursive strategy of predication (Wodak, 2001) and the rhetorical strategy of refutation by wit (Corbett \& Connors, 1999).

The predication strategy is suitable to pollute as opponents can be constructed as 'irrational' through assigning various negative traits to them. In our study, this was done by portraying governments of developing countries, NGOs and anti-globalists as self-interested, unreliable, narrow-minded, unreasonable and naïve. These negative traits do not only stage opponents as antagonists but also in ways that undermine their identity and authority position (Vaara, 2013). They are positioned as actors with low moral character, hereby destabilizing their criticism and rendering them less power to speak (cf. Lefsrud \& Meyer, 2012). The polluting of opponents further occurred by refutation by wit, a rhetorical tool that in legitimation studies has remained absent. Yet, it is a very powerful device to challenge a particular thesis because as quoted by Corbett and Connors $(1999$, p. 280$)$ "ridicule is the test of truth". Parody, sarcasm and irony can serve as effective tools to further pollute opponents' actor images as these rhetorical techniques can wittily reduce a well-presented argument to absurdity (Corbett \& Connors, 1999).

Discursive co-optation. Different from discursive antagonism, 'discursive co-optation' 
is a form of legitimation that engages with criticism by strategically appropriating previous opponents. Since Selznick (1949) identified co-optation as a process of absorbing challenging elements into established decision-making structures, processes of co-optation have been discussed in various contexts but central to co-optation is the idea of influencing and neutralizing the opposition (Oliver, 1991). Our discursive perspective similarly points to the appropriation of opponents, but highlights the textual strategy to do so. In particular, we note that the referential strategy serves as an effective tool, categorizing challenging actors no longer as opponents or belonging to the out-group but as partners whose goals aligns with its own goals. While our study indicates only referential strategy as a way to construct discursive co-optation, the work by Livesey (2002) indicates another textual strategy. In her study of ExxonMobile's advertorials on climate change, Livesey (2002, p. 128). sees “co-opting” as strategically appropriating "the very language and rhetorical position of the environmental movement". Multiple textual strategies of discursive co-optation are thus possible and future research may want to further explore how discursive co-opting can be produced, hereby appropriating criticism for incorporation into capitalist systems (Boltanski \& Chiapello, 2005).

Our study highlights discursive co-opting as strategically emphasizing dialogue and collaboration with challenging actors and this is likely to maintain as sense of legitimacy for two reasons. First, strategically staging previous opponents as becoming partners may alter the public perceptions about the intensity of the opposition. Successfully appropriating the mainstream, moderate groups within the opposition allows corporations to stage more progressive elements employing confrontational tactics as quibblers and radicals with unreasonable demands, which may result in these latter's marginalization (Winston, 2002). Second, and maybe even more important, discursive co-optation through partnership may indirectly contribute to the purification of one's own image. By representing former 
opponents differently, emphasizing dialogue and partnership, this discursive process tends to contribute in a suggestive and implicit way to an idealized image of the self. In our study, the co-opting of NGOs implicitly suggests an image of MNCs as morally responsible actors. It hints at a positive evolution of the MNC's morality over time, the injustice of past criticism on MNCs, and/or the existence of shared interests between global business, the developing world, and civil society in sustainable economic development issues. This suggestive aspect of discursive co-optation supports Vaara and colleagues' (2006) position that the 'unsaid' elements in texts may be also relevant for discursive analyses of legitimation.

As co-optation of opposition is considered to enhance legitimacy (Baur \& Schmitz, 2012; Dowling \& Pfeffer, 1975; Oliver, 1991), it is rather surprising that its discursive aspects have not yet been discussed in discursive legitimation research within management and organization studies. Yet, the neglect of historical context by previous research might precisely the reason for that. Considering the periodization in our study, we propose that discursive co-optation only arises when the discursive position of challenging actors has changed because of historical evolutions that make discursive co-optation possible. For instance, co-opting governments of developing countries was possible only because international relations had changed, influencing the attitude of industrializing developing countries towards MNCs. Similar, NGOs could be co-opted because of various CSR-related initiatives in which both actors collaborate.

We believe that discursive antagonism and discursive co-optation are valuable constructs to further develop the related concept of defensive institutional work as discussed by Maguire and Hardy (2009). While they understand the latter as "the purposive action of individuals and organizations aimed at countering disruptive institutional work", mainly under the form of "countering assertions regarding negative impacts, the inappropriateness of practices, and the need for regulation" (p.169), our study puts forward that countering or 
antagonistic response can also take the form of creating actor images, both in terms of purifying one's own image and polluting the image of the critics. Our findings further suggest that countering disruptive assertions is not only about contesting or disputing criticism but also about discursively co-opting critics.

Dynamic interplay of discursive antagonism and discursive co-optation. Finally, when discursive co-optation arose as a prominent legitimation process in the public debate, we note that the characteristics of discursive antagonism changed significantly. In particular, the latter transformed into a legitimation process that is fully complementary with discursive cooptation. We see this transformation in two ways. First, our findings suggest that the polluting aspect of discursive antagonism completely disappears. The emphasis on partnerships and dialogue leaves little room for polluting the images of traditional opponents as staging the latter as becoming partners is contradictory with staging these same actors as unreliable and undermining their arguments through humor. In addition, we see that in combination with discursive co-optation, discursive antagonism can only produce a particular type of purification of the self. In the final phase, when discursive co-optation was very prominent, there were no longer distinctly positive portrayals of MNCs as during the previous decades. Rather, confronted with the legitimacy issue of tax evasion, discursive antagonism occurred primarily by constructing a self- image as 'morally neutral'. So, the purification of the self occurred in a more cautious way, very likely to avoid polemic that would undermine public perceptions about dialogue and partnerships between business and civil society. This latter is probably also the reason why the discursive strategy of 'amoralization' has hitherto not been discussed in previous studies on the legitimation of controversies. Examining discursive legitimation in the immediate aftermath of a scandal, studies are very likely to find polemic strategies and not the more cautious ways of purifying the self. Overall, these transformations thus support the view that discursive co-optation can be considered as the establishment's 
ability to "bend without breaking" (Campbell, 2001, p. 354) when faced with societal opposition and protest.

\section{MNCs as Political CSR Actors: The Result of Historical Processes}

Taking MNCs as the empirical case under examination, our study further contributes to the way in which we understand the role of this type of organization in current global society. In particular, we suggest to see the recent phenomenon of MNCs taking up social and political responsibilities that go beyond legal requirements (Matten \& Crane, 2005; Scherer \& Palazzo, 2011) as a historical product of the legitimation process that MNCs faced in the past decades.

Within the business ethics literature, scholars increasingly concentrate on the phenomenon that MNCs are increasingly engaged in activities that have traditionally been regarded as nation-state activities. Examples are their involvement in all kinds of selfregulatory initiatives, and engagement in multi-stakeholder initiatives around labor standards, human rights, natural environment, public health or education (Matten \& Crane, 2005; Scherer \& Palazzo, 2011). Typically, this phenomenon of so-called 'political CSR' where MNCs are conceived as political actors is explained by reference to the conditions of globalization and in particular to the post-national constellation in which the decline of the power of the nation-state is emphasized. It is this regulatory vacuum in global governance that is put forward as the main cause for the social and political activities of MNCs.

By considering the historical process of MNCs' legitimation, our study offers a complementary interpretation of how to understand the emergence of political CSR. In particular, our findings suggest that MNCs' engagements in such initiatives can be understood in light of the characteristics of the controversies which MNCs have faced during the past decades. From the anti-globalist era onwards, civil society actors have brought MNCs' moral responsibilities (beyond strict legal obligations) to the foreground in a number of highly 
mediatized environmental and human rights scandals. Such a strong emphasis on corporate moral responsibility in the public debate was a new development at that time. Until then, public controversies over the MNC were primarily located in the regulatory sphere, revolving around the promulgation and content of universal codes of conduct intended to confine the uncontrolled power of MNCs in global society. This shift in controversy goes further hand in hand with a change in opponents and their discursive power position. While the governments of developing countries were not able to make MNCs the subject of an intense public debate, Western NGOs and anti-globalization activists managed to do so. Considering this change in controversy and opponents, we suggest that the global business world has strategically responded to the increased societal calls for corporate moral responsibility during and after the anti-globalist era by engaging in political CSR initiatives. In addition to seeing these initiatives as political actions in a vacuum of global governance, we thus consider them to be strategic practices that intend to re-establish a sense of legitimacy for MNCs and to prevent future controversies of occurring.

\section{Concluding Reflections}

Historical accounts such as this one are always constructed in nature, being the final outcome of a myriad of intentional and unintentional choices during the research process with regard to publication formats, interpretations, and all kinds of methodological issues (Bell \& Taylor, 2013; Rowlinson et al., 2014; Suddaby et al., 2014). The format of a journal article within the field of management and organization studies, for instance, provides only limited space for the interpretation of complex processes over time and in their historical context (especially in comparison with books), which means that certain nuances were inevitably lost during our writing process (Yates, 2014). And while our analysis of articles in The Economist is conducted in a rigorous and systematic way, interpretations of such 'traces of the past' can 
never be completely apolitical and value- or ideology-free. When engaging with traces of the past, the kind of questions we ask and the interpretations we make are influenced by the conditions of our present context (Weatherbee, 2012). This implies that our historical account is not a neutral representation of historical facts and developments. Rather, it should be considered as a political act, reproducing and/or challenging the current societal status-quo through the use of certain vocabularies (cf. Alvesson \& Sköldberg, 2009; Bell \& Taylor, 2013).

Despite the fast-growing stream of literature on the integration of historical perspective and methods into management and organization studies, we felt that crafting an empirical study that may be deemed authentic within the realms of both disciplines remains a challenging undertaking. Especially combining the historian's aim to situate phenomena in their unique 'temporal and spatial context' and the organization theorist's preference for the distillation of generalizable insights and more universal truth claims places serious theoretical and methodological demands on researchers. We believe, however, that our study is to an acceptable degree authentic to the ambitions of both disciplines. While we provide a historically contextualized account of how the MNC was legitimized by The Economist during the current wave of globalization, we also propose two new constructs - discursive antagonism and discursive co-optation - that may be of value to understand other cases of legitimation over time. We hope that our study may further stimulate the analysis of discursive legitimation of other contested actors and controversial actions from a historical perspective, especially in cases around ethical issues and responsible business practices (cf. Rowlinson, Jacques \& Booth, 2009). To quote Jacques (1996, p. 190), such a perspective will be "invaluable", if the field of organization studies is "expected to provide a critically reflective vision of the good society, or inform debate between alternative visions of that society". 


\section{REFERENCES}

Alexander, J. C., \& Smith, P. (1993). The discourse of American civil society: A new proposal for cultural studies. Theory and Society, 22, 151-207.

Alvesson, M., \& Sköldberg, K. (2009). Reflexive methodology: New vistas for qualitative research. London: Sage.

Banerjee, S. B. (2010). Governing the global corporation: a critical perspective. Business Ethics Quarterly, 20, 265-274.

Baur, D., \& Schmitz, H. P. (2012). Corporations and NGOs: When accountability leads to cooptation. Journal of Business Ethics, 106, 9-21.

Bell, E., \& Taylor, S. (2013). Writing history into management research. Management \& Organizational History, 8, 127-136.

Boltanski, L., \& Chiapello, E. (2005). The new spirit of capitalism. London: Verso.

Breeze, R. (2012). Legitimation in corporate discourse: Oil corporations after Deepwater Horizon. Discourse \& Society, 23, 3-18.

Brown, A. D., Ainsworth, S., \& Grant, D. (2012). The rhetoric of institutional change. Organization Studies, 33, 297-321.

Burchell, J., \& Cook, J. (2013). CSR, co-optation and resistance: The emergence of new agonistic relations between business and civil society. Journal of Business Ethics, 115, 741-754.

Campbell, D. (2001). Conviction seeking efficacy: Sustainable agriculture and the politics of co-optation. Agriculture and Human Values, 18, 353-363.

Corbett, E. P. J., \& Connors, R. J. (1999). Classical rhetoric for the modern student. New York: Oxford University Press.

Crane, A. (2000). Corporate greening as amoralization. Organization Studies, 21, 673-696.

Dowling, J., \& Pfeffer, J. (1975). Organizational legitimacy: social values and organizational 
behavior. Pacific Sociological Review, 18, 122-136.

Eckes Jr., A. E. (2011). The contemporary global economy: A history since 1980. Chichester: Wiley-Blackwell.

Erkama, N., \& Vaara, E. (2010). Struggles over legitimacy in global organizational restructuring: A rhetorical perspective on legitimation strategies and dynamics in a shutdown case. Organization Studies, 31, 813-839.

Fear, J. (2014). Mining the past: historicizing organizational learning and change. In M. Bucheli \& R. D. Wadhwani (Eds.), Organizations in time: History, theory, methods (pp. 169-191). Oxford: Oxford University Press.

Fieldhouse, D. K. (1986). The multinational: a critique of a concept. In A. Teichova, M. Lévy-Leboyer \& H. Nussbaum (Eds.), Multinational enterprise in historical perspective (pp. 9-40). Cambridge: Cambridge University Press.

Fiss, P. C., \& Hirsch, P. M. (2005). The discourse of globalization: Framing and sensemaking of an emerging concept. American Sociological Review, 70, 29-52.

Glynn, M. A., \& Lounsbury, M. (2005). From the critics' corner: Logic blending, discursive change and authenticity in a cultural production system. Journal of Management Studies, $42,1031-1055$.

Goodrick, E., \& Reay, T. (2010). Florence Nightingale endures: legitimizing a new professional role identity. Journal of Management Studies, 47, 55-84.

Green, S. E., Li, Y., \& Nohria, N. (2009). Suspended in self-spun webs of significance: A rhetorical model of institutionalization and institutionally embedded agency. Academy of Management Journal, 52, 11-36.

Hamdani, K., \& Ruffing, L. (2015). United Nations Centre on Transnational Corporations: corporate conduct and the public interest. New York: Routledge.

Hargadon, A. B., \& Douglas, Y. (2001). When innovations meet institutions: Edison and the 
design of the electric light. Administrative Science Quarterly, 46, 476-501.

Hoffman, A. J. (1999). Institutional evolution and change: Environmentalism and the US chemical industry. Academy of Management Journal, 42, 351-371.

Jacobs, R. N. (1996). Civil society and crisis: Culture, discourse, and the Rodney King beating. American Journal of Sociology, 101, 1238-1272.

Jacques, R. (1996). Manufacturing the employee: Management knowledge from the 19th to 21st centuries. London: Sage.

Jones, G. (2008). Globalization. In G. Jones \& J. Zeitlin (Eds.), The Oxford handbook of business history (pp. 141-168). Oxford: Oxford University Press.

Joutsenvirta, M. (2013). Executive pay and legitimacy: Changing discursive battles over the morality of excessive manager compensation. Journal of Business Ethics, 116, 459-477.

Joutsenvirta, M., \& Vaara, E. (2009). Discursive (de)legitimation of a contested Finnish greenfield investment project in Latin America. Scandinavian Journal of Management, 25, $85-96$.

Joutsenvirta, M., \& Vaara, E. (2015). Legitimacy struggles and political corporate social responsibility in international settings: a comparative discursive analysis of a contested investment in Latin America. Organization Studies, 36, 741-777.

Kell, G. (2013). 12 Years later reflections on the growth of the UN Global Compact. Business \& Society, 52, 31-52.

Kipping, M., \& Üsdiken, B. (2014). History in organization and management theory: More than meets the eye. The Academy of Management Annals, 8, 535-588.

Klein, N. (1999). No logo: Taking aim at the brand bullies. New York: Picador.

Klein, N. (2007). The shock doctrine: The rise of disaster capitalism. Toronto: Knopf Canada.

Kobrin, S. J. (2005). Multinational corporations, the protest movement, and the future of global governance. In A. D. Chandler Jr. \& B. Mazlish (Eds.), Leviathans: Multinational 
corporations and the new global history (pp. 219-235). Cambridge: Cambridge University Press.

Leblebici, H., Salancik, G. R., Copay, A., \& King, T. (1991). Institutional change and the transformation of interorganizational fields: An organizational history of the US radio broadcasting industry. Administrative Science Quarterly, 36, 333-363.

Lefsrud, L. M., \& Meyer, R. E. (2012). Science or science fiction? Professionals' discursive construction of climate change. Organization Studies, 33, 1477-1506.

Levy, D., \& Kaplan, R. (2008). CSR and theories of global governance: strategic contestation in global issue arenas. In A. Crane, A. McWilliams, D. Matten, J. Moon \& D. S. Siegel (Eds.), The Oxford handbook of corporate social responsibility (pp. 432-451). New York: Oxford University Press.

Lilienthal, D. (1960). The multinational corporation. In M. Anshen \& G. L. Bach (Eds.), Management and corporations 1985. A symposium held on the occasion of the $10^{\text {th }}$ anniversary of the Graduate School of Industrial Administration (pp. 119-158). Westport: Carnegie Institute of Technology.

Livesey, S. M. (2001). Eco-identity as discursive struggle: Royal Dutch/Shell, Brent Spar, and Nigeria. Journal of Business Communication, 38, 58-91.

Livesey, S. M. (2002). Global warming wars: rhetorical and discourse analytic approaches to ExxonMobil's corporate public discourse. Journal of Business Communication, 39, 117146.

Maclean, M., Harvey, C., \& Clegg, S. R. (in press). Conceptualizing historical organization studies. Academy of Management Review.

Maguire, S., \& Hardy, C. (2009). Discourse and deinstitutionalization: The decline of DDT. Academy of Management Journal, 52, 148-178.

Mäkinen, J., \& Kourula, A. (2012). Pluralism in political corporate social responsibility, 
Business Ethics Quarterly, 22, 649-678.

Matten, D., \& Crane, A. (2005). Corporate citizenship: towards an extended theoretical conceptualization. Academy of Management Review, 30, 166-179.

Mazower, M. (1998). Dark continent: Europe's 20th century. New York: AA Knopf.

Murphy, S. D. (2005). Taking multinational corporate codes of conduct to the next level. Columbia Journal of Transnational Law, 43, 389-433.

Navis, C., \& Glynn, M. A. (2010). How new market categories emerge: Temporal dynamics of legitimacy, identity, and entrepreneurship in satellite radio, 1990-2005. Administrative Science Quarterly, 55, 439-471.

Norberg, J. (2003). In defense of global capitalism. Washington: Cato Institute.

Oliver, C. (1991). Strategic responses to institutional processes. Academy of Management Review, 16, 145-179.

Patriotta, G., Gond, J. P., \& Schultz, F. (2011). Maintaining legitimacy: Controversies, orders of worth, and public justifications. Journal of Management Studies, 48, 1804-1836.

Perelman, C., \& Olbrechts-Tyteca, L. (1969). The new rhetoric: A treatise on argumentation. London: University of Notre Dame Press.

Rojas, F. (2010). Power through institutional work: Acquiring academic authority in the 1968 third world strike. Academy of Management Journal, 53, 1263-1280.

Rowlinson, M., Hassard, J., \& Decker, S. (2014). Research strategies for organizational history: A dialogue between historical theory and organization theory. Academy of Management Review, 39, 250-274.

Rowlinson, M., Jacques, R. \& Booth, C. (2009). Critical management and organizational history. In M. Alvesson, T. Bridgman \& H. Willmott (Eds.), The Oxford handbook of critical management studies (pp. 286-303). Oxford: Oxford University Press.

Sagafi-nejad, T. (2008). The UN and transnational corporations: From code of conduct to 
Global Compact. Bloomington: Indiana University Press.

Scherer, A. G., \& Palazzo, G. (2007). Toward a political conception of corporate responsibility: Business and society seen from a Habermasian perspective. Academy of Management Review, 32, 1096-1120.

Scherer, A. G., \& Palazzo, G. (2011). The new political role of business in a globalized world: A review of a new perspective on CSR and its implications for the firm, governance and democracy. Journal of Management Studies, 48, 899-931.

Selznick, P. (1949). TVA and the grass roots: A study in the sociology of formal organization. Berkeley: University of California Press.

Sillince, J. A., \& Brown, A. D. (2009). Multiple organizational identities and legitimacy: the rhetoric of police websites. Human Relations, 62, 1829-1856.

Stanley, T. W. (1980). International codes of conduct for MNC's: a skeptical view of the process. American University Law Review, 30, 973- 1008.

Suddaby, R., Foster, W. M., \& Mills, A. J. (2014). Historical institutionalism. In M. Bucheli \& R. D. Wadhwani (Eds.), Organizations in time: History, theory, methods (pp. 100-123). Oxford: Oxford University Press.

Suddaby, R., \& Greenwood, R. (2005). Rhetorical strategies of legitimacy. Administrative Science Quarterly, 50, 35-67.

Suddaby, R., \& Greenwood, R. (2009). Methodological issues in researching institutional change. In D. Buchanan \& A. Bryman (Eds.), The SAGE handbook of organizational research methods (pp. 177-195). London: Sage Publications.

Vaara, E. (2013). Struggles of legitimacy in mediatized society. Paper presented at the 'Connecting Rigor and Relevance in Institutional Analysis Conference' at Harvard Business School (June 3-4, 2013).

Vaara, E., \& Tienari, J. (2008). A discursive perspective on legitimation strategies in 
multinational corporations. Academy of Management Review, 33, 985-993.

Vaara, E., Tienari, J., \& Laurila, J. (2006). Pulp and paper fiction: on the discursive legitimation of global industrial restructuring. Organization Studies, 27, 789-810.

Van de Meerssche, P. (2006). Internationale politiek 1815-2005. Deel II: 1945-2005 [International relations 1815-2005. Part II: 1945-2005). Leuven: Acco.

Van Dijk, T. A. (1998). Ideology: A multidisciplinary approach. London: Sage.

Van Leeuwen, T. (2007). Legitimation in discourse and communication. Discourse \& Communication, 1, 91-112.

Van Leeuwen, T., \& Wodak, R. (1999). Legitimizing immigration control: a discoursehistorical analysis. Discourse Studies, 1, 83-118.

Vernon, R. (1998). In the hurricane's eye: The troubled prospects of multinational enterprises. Cambridge, MA: Harvard University Press.

Washington, M., \& Zajac, E. J. (2005). Status evolution and competition: Theory and evidence. Academy of Management Journal, 48, 282-296.

Weatherbee, T. G. (2012). Caution! This historiography makes wide turns: Historic turns and breaks in management and organization studies. Management \& Organizational History, 7, 203-218.

Winston, M. (2002). NGO strategies for promoting corporate social responsibility. Ethics \& International Affairs, 16, 71-87.

Wodak, R. (2001). The discourse-historical approach. In R. Wodak \& M. Meyer (Eds), Methods of critical discourse analysis (pp. 63-94). London: Sage Publications.

Yates, J. (2014). Understanding historical methods in organization studies. In M. Bucheli \& R. D. Wadhwani (Eds.), Organizations in time: History, theory, methods (pp. 265-283). Oxford: Oxford University Press.

Zhu, Y., \& McKenna, B. (2012). Legitimating a Chinese takeover of an Australian iconic 
firm: Revisiting models of media discourse of legitimacy. Discourse \& Society, 23, 525552. 
Table I. Periodization regarding MNC-related controversies during the current wave of globalization

\begin{tabular}{|c|c|c|c|}
\hline Characteristics of the phase & $\begin{array}{l}\text { 1964-1988 } \\
\text { The MNC within the North- } \\
\text { South dialogue }\end{array}$ & $\begin{array}{c}1995-2005 \\
\text { The MNC in the anti-globalist } \\
\text { era }\end{array}$ & $\begin{array}{l}\text { 2007-2012 } \\
\text { The MNC and the Great } \\
\text { Recession }\end{array}$ \\
\hline Focus of the controversy & $\begin{array}{l}\text { Need for universal codes of } \\
\text { conducts }\end{array}$ & $\begin{array}{l}\text { Societal calls for moral } \\
\text { responsibility of MNCs }\end{array}$ & $\begin{array}{l}\text { Corporate involvement in tax } \\
\text { evasion }\end{array}$ \\
\hline Actors involved & $\begin{array}{l}\text { Governments of developing } \\
\text { countries } \\
\text { Governments of developed } \\
\text { countries } \\
\text { Supranational organizations } \\
\text { Critical academics } \\
\text { Western labor unions }\end{array}$ & $\begin{array}{l}\text { Non-governmental } \\
\text { organizations } \\
\text { Anti-globalization activists } \\
\text { Governments of developing } \\
\text { countries }\end{array}$ & $\begin{array}{l}\text { Non-governmental } \\
\text { organizations } \\
\text { Governments of developed } \\
\text { countries } \\
\text { Anti-corporate activists } \\
\text { Supranational organizations }\end{array}$ \\
\hline Intensity & $\begin{array}{l}\text { Slightly visible with temporary } \\
\text { peak during the } 1970 \text { s }\end{array}$ & $\begin{array}{l}\text { Highly visible - polemic tone, } \\
\text { cover pages, long articles, and } \\
\text { cartoons }\end{array}$ & $\begin{array}{l}\text { Slightly visible - news on } \\
\text { MNCs overshadowed by } \\
\text { global economic crisis }\end{array}$ \\
\hline
\end{tabular}


Table II. Discursive strategies to construct a sense of legitimacy for MNCs

\begin{tabular}{|c|c|c|}
\hline Discursive strategies & Definition & Example \\
\hline Authorization & $\begin{array}{l}\text { referring to the authority of actors and } \\
\text { individuals in whom institutional authority } \\
\text { of some kind is vested (Van Leeuwen, } \\
\text { 2007). }\end{array}$ & $\begin{array}{l}\text { "And the UN study confirms that multinationals } \\
\text { help the balance of payments of developing } \\
\text { countries" (11-22-1975) }\end{array}$ \\
\hline Rationalization & $\begin{array}{l}\text { referring to the utility of specific actions } \\
\text { based on knowledge claims that are } \\
\text { accepted in a given context as relevant } \\
\text { (Vaara \& Tienari, 2008, Van Leeuwen, } \\
\text { 2007). }\end{array}$ & $\begin{array}{l}\text { "Multinationals have created } 2 \mathrm{~m} \text { jobs in the third } \\
\text { world, trivial in relation to its workforce but } \\
\text { appreciable set against its } 54 \mathrm{~m} \text { known unemployed } \\
\text { in 1973" (11-22-1975) }\end{array}$ \\
\hline Amoralization & $\begin{array}{l}\text { pointing to the moral neutrality of business } \\
\text { activities; not making an event the subject } \\
\text { of moral reflection (Crane, 2000) }\end{array}$ & $\begin{array}{l}\text { "Whom to blame for all this darting through } \\
\text { loopholes? Mr Levin chided companies for } \\
\text { practising "tax alchemy". But they are bound to } \\
\text { exploit weaknesses in the rules, if only to avoid } \\
\text { putting themselves at a competitive disadvantage" } \\
(09-29-2012)\end{array}$ \\
\hline Improvement & $\begin{array}{l}\text { comparing between a worse and a better } \\
\text { position, thereby implying a laudable } \\
\text { movement from the one to the other } \\
\text { (Sillince \& Brown, 2009, based on } \\
\text { Perelman \& Olbrechts-Tyteca, 1969) }\end{array}$ & $\begin{array}{l}\text { "Many big companies take moral issues more } \\
\text { seriously than ever" (07-20-1996) }\end{array}$ \\
\hline
\end{tabular}


Predicational strategy

Referential strategy

Refutation by wit labelling the opponents negatively through evaluative attributions of negative traits (Wodak, 2001)

constructing previous opponents as belonging to the 'in-group' of proponents (Wodak, 2001)

reducing the opponent's argument(s) to absurdity through sophisticated humor (Corbett \& Connors, 1999)
"They [MNCs] have been the easy targets of nongovernmental organisations (NGOs), which understand perfectly well the value to themselves, in prestige and membership, of running a campaign which succeeds in humbling a mighty corporation" (01-29-2000)

"The battle lines separating hard-nosed champions of profit from rock-throwing demonstrators are fading. Partnerships between firms and NGOs are springing up. Oxfam, an anti-poverty group, works closely with multinationals such as Unilever, a consumer-goods giant." (07-20-2007)

"The costs for ExxonMobil to reduce its production of fuels that may contribute to climate change, as Greenpeace demands, would be huge: arguably, shutting itself down. Even though environmentalists invaded its offices dressed in tiger suits (and though rivals such as BP do talk to NGOs), Exxon has refused to negotiate on this. ... But increasingly, firms may conclude that if they are going to have to live with NGOs, they need to know which ones will play fair. Wise firms should talk to those - and leave the others to their tiger costumes" (08-09-2003) 
Figure I: The changing nature of discursive legitimation over time: the case of the MNC

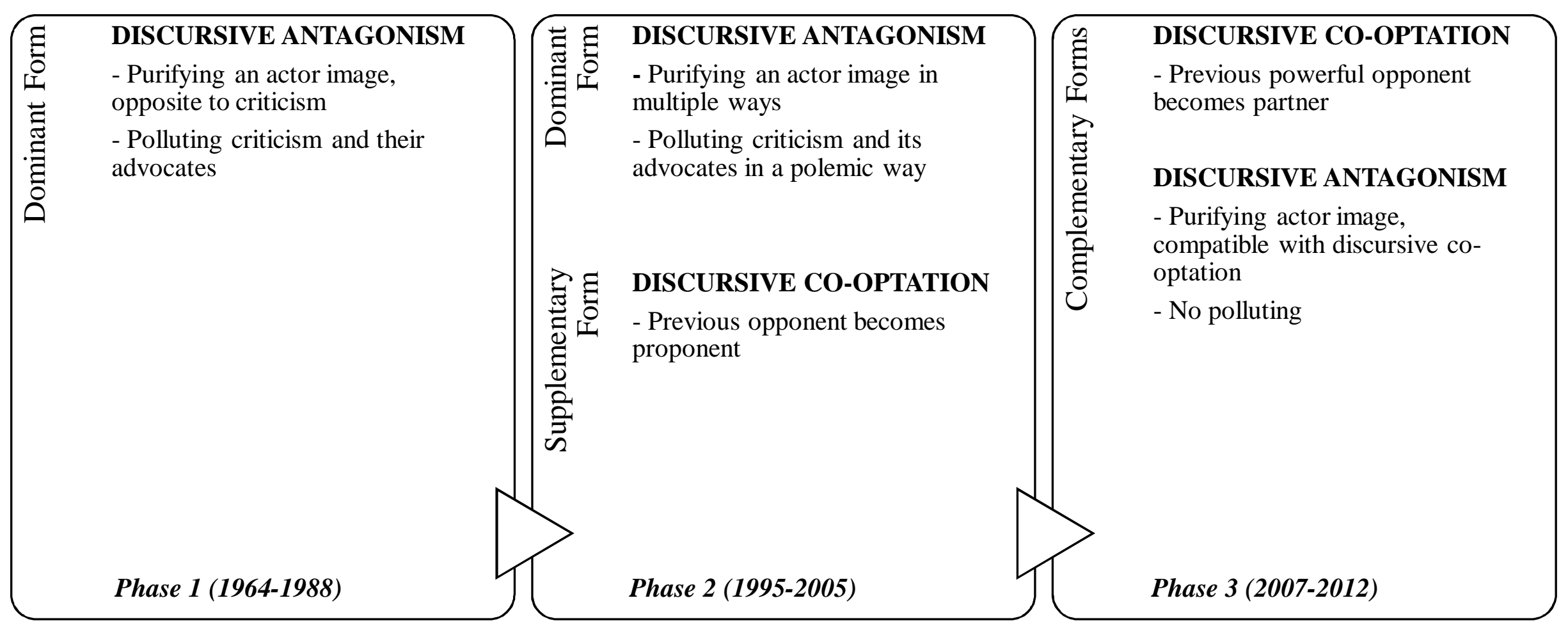

